\title{
Hairy/Enhancer-of-Split Related With YRPW Motif-Like Protein
}

National Cancer Institute

\section{Source}

National Cancer Institute. Hairy/Enhancer-of-Split Related With YRPW Motif-Like Protein. NCI Thesaurus. Code C114522.

Hairy/enhancer-of-split related with YRPW motif-like protein (328 aa, $235 \mathrm{kDa}$ ) is encoded by the human HEYL gene. This protein plays a role in both cardiac development and the negative regulation of transcription. 